\title{
Assessment of salt concentration in bread commonly consumed in the Eastern Mediterranean Region
}

Ayoub Al Jawaldeh ${ }^{1}$ and Manal Al-Khamaiseh ${ }^{2}$

'World Health Organization Regional Office for the Eastern Mediterranean, Cairo, Egypt (Correspondence to: Ayoub Al Jawaldeh: aljawaldeha@who. int). ${ }^{2}$ Royal Scientific Society, Amman, Jordan.

\begin{abstract}
Background: Hypertension is the most important cardiovascular risk factor in the World Health Organization (WHO) Eastern Mediterranean Region. Excessive salt and sodium intake is directly related to hypertension, and its reduction is a priority of WHO. Bread is the leading staple food in the Region; therefore, reducing the amount of salt added to bread could be an effective measure for reducing salt intake.
\end{abstract}

Aim: The study sought to determine the levels of sodium and salt in locally produced staple bread from 8 countries in the Region.

Methods: Bread samples were collected randomly from bakeries located in the capital cities of the selected countries. The samples were analysed for sodium content using atomic absorption spectroscopy.

Results: The mean salt content of breads varied from $4.28 \mathrm{~g} / \mathrm{kg}$ in Jordan to $12.41 \mathrm{~g} / \mathrm{kg}$ in Tunisia. The mean salt and sodium content in bread for all countries was 7.63 (SD 3.12) and 3.0 (SD 1.23) g/kg, respectively. The contribution of bread to daily salt intake varied considerably between countries, ranging from $1.3 \mathrm{~g}$ (12.5\%) in Jordan to $3.7 \mathrm{~g}$ (33.5\%) in Tunisia.

Conclusion: Interventions to reduce population salt intake should target reduction of salt in bread in all countries. The amount of salt added to bread should be standardized and relevant legislation developed to guide bakers. Setting an upper limit for salt content in flat bread (pita or Arabic bread) at $0.5 \%$ is strongly recommended. However, salt levels at $\leq 1 \%$ would be appropriate for other kind of breads.

Keywords: Salt, sodium, bread, noncommunicable disease, Eastern Mediterranean Region

Citation: Al Jawaldeh A, Al-Khamaiseh M. Assessment of salt concentration in bread commonly consumed in the Eastern Mediterranean Region. East Mediterr Health J. 2018;24(1):18-24. https://doi.org/10.26719/2018.24.1.18

Received: 10/07/17; accepted: 05/02/18

Copyright (C) World Health Organization (WHO) 2018. Some rights reserved. This work is available under the CC BY-NC-SA 3.o IGO license (https:// creativecommons.org/licenses/by-nc-sa/3.o/igo)

\section{Introduction}

The average salt intake of $>12 \mathrm{~g}$ /day per person in the World Health Organization (WHO) Eastern Mediterranean Region is higher than in most other regions in the world (1). In fact, it is more than double the amount recommended by WHO of $<5$ g/day or $2 \mathrm{~g}$ /day of sodium for adults. For children the recommendation is lower and depends on their calorie intake (2). Salt is the main source of sodium intake in the diet, accounting for almost $100 \%$ of daily sodium intake, with the majority (> 85\%) being excreted by the kidneys (3). Sodium is essential for maintenance of plasma volume, acid-base balance, transmission of nerve impulses and normal cell function. However, in excess it causes body fluid imbalance and presents a challenge for excretion by the kidneys, which potentially affects blood pressure and increases the risk of noncommunicable diseases (NCDs) (4). There is a significant positive correlation between high dietary sodium intake and increase in blood pressure in adults and children, and clinical trials have demonstrated that lowering sodium intake reduces blood pressure among individuals with normal as well as high blood pressure (5). High blood pressure is a predisposing factor for cardiovascular diseases and a number of other noncommunicable diseases (NCDs) (6). NCDs are the leading cause of death in the Region; 2.2 million lives are lost to NCDs annually, of which $51 \%$ are premature and occur among people aged $<70$ years (6). The burden of NCDs is progressively increasing. Projections indicate that there will be an alarming increase in their prevalence, with the 4 main NCDs causing 2.4 million deaths in 2025 , unless serious action is taken (7). This scenario represents the second highest projected increase among the $6 \mathrm{WHO}$ Regions (7). The growing burden of NCDs in the Eastern Mediterranean Region calls for urgent public health action to tackle unhealthy diet ( 1 of the 4 key risk factors), including implementation of policies to reduce levels of salt in foods.

There is evidence that salt reduction is a high-impact, preventive intervention that can considerably reduce the burden of NCD-related morbidity and mortality (6). A reduction in dietary intake of sodium of 50 $\mathrm{mmol} /$ day could reduce the number of people needing antihypertensive therapy by $50 \%$, the number of deaths from strokes by $22 \%$ and the number of deaths from coronary heart disease by $16 \%$ (8). Studies conducted in the United States of America (USA) indicated that a $3 \mathrm{~g}$ reduction in daily salt intake was associated with a 
significant decrease in the annual incidence of coronary heart disease, stroke, myocardial infarction, and all-cause mortality, which resulted in an estimated decrease in annual healthcare costs of US\$10-24 billion (9). Other studies have shown that decreasing sodium intake to < $2.3 \mathrm{~g}$ /day improved conduit artery and resistance vessel endothelial function, improved bioavailability of $\mathrm{NO}$ and reduced oxidative stress in middle aged and older adults with elevated systolic blood pressure (10). On the basis of this and other evidence the need to reduce salt in food was recognized by the United Nations General Assembly at a high-level meeting on NCDs in 2011 (11). A 30\% relative reduction in mean population salt intake by 2025 was enshrined as one of the voluntary global NCD targets set out in the Global Action Plan for the Prevention and Control of NCDs, endorsed by the World Health Assembly in 2013 $(12,13)$.

Entrenched within an overall dietary pattern, sodium intake may come from salt added to cooking or at the table, which is under an individual's control, but also comes from salt in processed or prepared foods (14). In some countries the major source of dietary sodium is salt added during food preparation, whereas in other countries, processed food products contribute most of the salt in the diet. In the United Kingdom of Great Britain and Northern Ireland (UK) and USA processed foods contribute $>70 \%$ of the dietary salt intake, whereas in China, $76 \%$ of total salt intake is discretionary (15). Similarly, sources of dietary salt in the Eastern Mediterranean Region vary between low-, middle- and high-income countries due to varying dietary patterns (2). The nutrition transition in the Region has resulted in diets dominated by processed products such as bread, crackers, processed meats, cheese and snack foods and these contribute considerably to the high salt consumption in the Region (1). Observational studies have indicated that bread is the leading staple food in the Region; therefore, reducing the amount of salt added to bread could be an effective measure for the prevention and control of NCDs.

There is a lack of information on the salt content of bread in the Region. Therefore, we conducted an indicative study to measure the salt content in bread from different countries in the Region, so that policymakers can decide on the appropriate action to achieve salt reduction and whether bread is a priority for such action in the Member States.

\section{Methods}

\section{Sample size}

The initial plan was to collect 10 samples of staple bread. This is defined as bread that is eaten routinely and in such quantities that it constitutes a dominant portion of the standard diet for a given population, supplying a large fraction of energy needs. We sent a message to all WHO and Ministry of Health focal points in each Member State. One hundred and five bread samples were collected randomly during 1 November to 15 December 2013, which responded to the study, namely Bahrain, Egypt, Jordan,
Kuwait, Qatar, Oman, Lebanon and Tunisia. Bread samples were collected from different bakeries in the capital city of each country; one sample from each bakery. Bread samples were packed in airtight plastic bags, stored under cool, dry conditions and transported to the Royal Scientific Society, Jordan by courier for analysis. Each sample weighed $\geq 150 \mathrm{~g}$. The original samples were all flat bread, which is the most popular form in the Middle East, which is also called Khubz Arabi and is now widely known as pita bread. This applied to all countries involved in the study, except Tunisia, where round, thick Frenchtype bread was dominant.

\section{Sample preparation}

The bread samples were ground to form a homogeneous composition, packed and stored in airtight plastic bags at $15^{\circ} \mathrm{C}$ until use. The samples were analysed for sodium content and the results were used to estimate the population sodium intake resulting from bread consumption in the selected countries.

\section{Determination of sodium and moisture content}

The sodium and moisture contents of bread were determined using Association of Official Analytical Chemists (AOAC) methods. Moisture content was determined by drying samples in an oven at $105^{\circ} \mathrm{C}$ to eliminate all moisture in the sample. Analysis of sodium was carried out with the atomic absorption technique after digestion of samples with nitric acid. For this purpose, 5-10 g bread samples were weighed accurately and transferred to the digestion flask and $25 \mathrm{ml}$ nitric acid was added. The digestion flasks were placed on a sand bath at $200^{\circ} \mathrm{C}$ for 1 hour until the whole organic matter was completely digested. The digested material was transferred to a 100-ml volumetric flask and the volume made up to the mark with deionized water. The samples were analysed for sodium content using atomic absorption and calculated on a dry weight basis. Standard solutions for sodium were prepared and the wavelength readings used to construct a calibration curve. Sodium was read off at $589 \mathrm{~nm}$ and sodium content calculated as described below.

For calculation of sodium content on a dry weight basis the following formula was used:

\begin{tabular}{|c|c|}
\hline \multirow{2}{*}{$\begin{array}{l}\text { Sodium on dry } \\
\text { weight basis= }\end{array}$} & $\begin{array}{l}\text { Sodium content on } \\
\text { wet basis }(\mathrm{Na})\end{array}$ \\
\hline & o - Moisture conten \\
\hline
\end{tabular}

For calculation of salt content in the sample, the following formula was used:

Sodium content $(\mathrm{Na}) \times$ Molecular weight of $\mathrm{NaCl}$

Salt content $(\mathrm{NaCl})=$

Atomic weight of $\mathrm{Na}$ 
Standard deviations for the mean values between the countries were calculated.

\section{Results}

The mean levels of salt and sodium in bread samples collected from the 8 countries were 7.63 (standard deviation 3.12) g/ $\mathrm{kg}$ and $3.0(1.23) \mathrm{g} / \mathrm{kg}$, respectively (Table 1). The highest salt content was found in Tunisia and Kuwait and the lowest in Egypt and Jordan. The standard deviation shows that there was considerable variation of salt content among the countries. The contribution of bread to daily salt intakes varied considerably among the countries, ranging from $1.3 \mathrm{~g}(12.5 \%)$ in Jordan to $3.7 \mathrm{~g}$ (33.5\%) in Tunisia, based on a $300 \mathrm{~g}$ daily bread intake in most countries of the Region.

\section{Discussion}

WHO recommends salt reduction in food as one of the cost-effective interventions to control and prevent NCDs. The present study revealed that levels of salt varied within the same type of bread. For example, the level was high in Kuwait $10.97 \mathrm{~g} / \mathrm{kg}$ (1.1\%), while Jordan produced the same flat bread at a level of $4.28 \mathrm{~g} / \mathrm{kg}$ (0.43\%), which means that Kuwait could reduce the salt content in bread without any concern related to the palatability or physical properties of the bread. This also applies to Bahrain and Oman. The highest level of salt was found in the Frenchtype rounded thick bread produced in Tunisia $12.41 \mathrm{~g} / \mathrm{kg}$ (1.24\%), which contributed to $3.2 \mathrm{~g}$ of salt intake daily. This represents $64 \%$ of the recommended salt intake level set by $\mathrm{WHO}$ (< $5 \mathrm{~g} /$ day/person).

Although the level of salt in flat bread produced in the Eastern Mediterranean Region is not as high as in
European bread (1.5-3\%) (16), it still represents a major source of salt intake considering that bread is a staple food in the Region and consumed in high quantities by most of the population. Therefore, salt reduction in bread could contribute to reduction of salt intake in the Region. The WHO Regional Office for the Eastern Mediterranean set a target for $30 \%$ reduction in salt content as a strategic intervention in the next 3 years.

Technical limitations are rarely a reason to drop bread from a salt reduction programme. Within almost every food category, there is already a broad range of salt levels across similar products that demonstrate the technical feasibility of producing lower salt options. For example, rapid assessment shows that flat bread can be produced with salt levels as low as $0.4 \%$ on wet basis, as in Jordan and Egypt. Setting a target for salt content in bread of up to $0.5 \%(5.0 \mathrm{~g} / \mathrm{kg}$ bread) is technically possible.

Encouraging the food industry to reformulate its products can be challenging. Several arguments may be used by the industry to justify the difficulty of reducing salt content in some foods, including bread. However, experience from around the world has shown that it is technically possible to reduce the amount of salt significantly without affecting the product. In the UK, for example, the salt content of processed foods sold in supermarkets was initially reduced by $20-30 \%$ over 3 years without affecting consumer preference or sales (17). In the UK it was estimated that, for a total campaign cost of $£ 15$ million to reduce daily salt intake, $£ 1.5$ billion per year would be saved in health care (1). The present study showed that average salt content in Tunisia and Kuwait is $>1 \%$ in bread, which accounts for 33.5 and $33.9 \%$ of total salt intake, respectively (Table 1). Similar findings have been reported in the Islamic Republic of Iran and

Table 1. Content of sodium and salt in samples of bread mostly consumed in selected countries of the Eastern Mediterranean Region ( on wet basis)

\begin{tabular}{|c|c|c|c|c|c|c|c|c|c|}
\hline Country & Type of bread & $\begin{array}{l}\text { No. of } \\
\text { Samples }\end{array}$ & $\begin{array}{l}\text { Sodium } \\
\text { content in } \\
\text { wet basis } \\
\text { (ppm) }\end{array}$ & $\begin{array}{l}\text { Sodium } \\
\text { content in } \\
\text { wet basis } \\
(\mathrm{g} / \mathrm{kg})\end{array}$ & $\begin{array}{l}\text { Solt } \\
\text { content in } \\
\text { wet basis } \\
(\mathrm{g} / 100 \mathrm{~g})\end{array}$ & $\begin{array}{l}\text { Salt } \\
\text { content } \\
\text { in } \mathrm{g} / \mathrm{kg}\end{array}$ & $\begin{array}{l}\text { Estimated } \\
\text { daily } \\
\text { intake of } \\
\text { salt from } \\
\text { bread } \\
\text { (300g/d/ } \\
\text { person) }\end{array}$ & $\begin{array}{l}\text { Estimated } \\
\text { daily* salt } \\
\text { intake } \\
\text { g/d/ } \\
\text { person }\end{array}$ & $\begin{array}{l}\text { Percentage } \\
\text { of bread } \\
\text { contribution } \\
\text { to totoal salt } \\
\text { intake (g/d/ } \\
\text { person) }\end{array}$ \\
\hline \multirow[t]{4}{*}{ Bahrain } & $\begin{array}{l}\text { Sliced bread } \\
\text { (French type) }\end{array}$ & 5 & 2631.9 & 2.6 & 0.67 & 6.69 & 2.0 & - & - \\
\hline & $\begin{array}{l}\text { Arabic bread } \\
\text { (pita) }\end{array}$ & 5 & 2634.9 & 2.6 & 0.67 & 6.70 & 2.0 & - & - \\
\hline & $\begin{array}{l}\text { Flat bread } \\
\text { (Lebanese) }\end{array}$ & 10 & 5260.7 & 5.3 & 1.34 & 13.37 & 4.0 & - & - \\
\hline & Mean & & 3509.2 & 3.5 & 0.89 & 8.92 & 2.7 & 13.5 & 19.8 \\
\hline \multirow[t]{4}{*}{ Oman } & $\begin{array}{l}\text { White sliced } \\
\text { bread (French } \\
\text { type) }\end{array}$ & 5 & 3662.2 & 3.7 & 0.93 & $9 \cdot 31$ & 2.8 & - & - \\
\hline & Samoon bread & 4 & 4701.9 & 4.7 & 1.20 & 11.95 & 3.6 & - & - \\
\hline & $\begin{array}{l}\text { Flat Arabic bread } \\
\text { (Lebanese) }\end{array}$ & 6 & 2312.5 & 2.3 & 0.59 & 5.88 & 1.8 & - & - \\
\hline & Mean & & 3558.9 & 3.6 & 0.91 & 9.05 & 2.7 & 9.5 & 28.6 \\
\hline
\end{tabular}




\begin{tabular}{|c|c|c|c|c|c|c|c|c|c|}
\hline Country & Type of bread & $\begin{array}{l}\text { No. of } \\
\text { Samples }\end{array}$ & $\begin{array}{l}\text { Sodium } \\
\text { content in } \\
\text { wet basis } \\
\text { (ppm) }\end{array}$ & $\begin{array}{l}\text { Sodium } \\
\text { content in } \\
\text { wet basis } \\
\text { (g/kg) }\end{array}$ & $\begin{array}{l}\text { Solt } \\
\text { content in } \\
\text { wet basis } \\
\text { (g/100 g) }\end{array}$ & $\begin{array}{l}\text { Salt } \\
\text { content } \\
\text { in } \mathrm{g} / \mathrm{kg}\end{array}$ & $\begin{array}{l}\text { Estimated } \\
\text { daily } \\
\text { intake of } \\
\text { salt from } \\
\text { bread } \\
\text { (300g/d/ } \\
\text { person) }\end{array}$ & $\begin{array}{l}\text { Estimated } \\
\text { daily }^{*} \text { salt } \\
\text { intake } \\
\text { g/d/ } \\
\text { person }\end{array}$ & $\begin{array}{l}\text { Percentage } \\
\text { of bread } \\
\text { contribution } \\
\text { to totoal salt } \\
\text { intake (g/d/ } \\
\text { person) }\end{array}$ \\
\hline \multirow[t]{3}{*}{ Egypt } & $\begin{array}{l}\text { Baladi refined } \\
\text { bread (Ayash) }\end{array}$ & 5 & 1582.5 & 1.6 & 0.40 & 4.02 & 1.2 & - & - \\
\hline & $\begin{array}{l}\text { Baladi ordinary } \\
\text { (Ayash) }\end{array}$ & 5 & 2010.1 & 2.0 & 0.51 & 5.11 & 1.5 & - & - \\
\hline & Mean & & 1796.3 & 1.8 & 0.46 & 4.57 & 1.4 & 9.2 & 14.9 \\
\hline \multirow[t]{5}{*}{ Kuwait } & $\begin{array}{l}\text { Flat Arabic thin } \\
\text { bread (brown) }\end{array}$ & 3 & 3319.4 & 3.3 & 0.84 & 8.44 & 2.5 & - & - \\
\hline & $\begin{array}{l}\text { Flat thin Arabic } \\
\text { bread (white) }\end{array}$ & 4 & 3330.6 & 3.3 & 0.85 & 8.47 & 2.5 & - & - \\
\hline & $\begin{array}{l}\text { Flat Arabic bread } \\
\text { (white) }\end{array}$ & 4 & 6087.5 & 6.1 & 1.55 & 15.48 & 4.6 & - & - \\
\hline & $\begin{array}{l}\text { Flat Arabic bread } \\
\text { (brown) }\end{array}$ & 2 & 4516.5 & 4.5 & 1.15 & 11.48 & 3.4 & - & - \\
\hline & Mean & & 4313.5 & 4.3 & 1.10 & 10.97 & 3.3 & 9.7 & 33.9 \\
\hline \multirow[t]{2}{*}{ Tunisia } & French bread & 10 & 4881.7 & 4.9 & 1.24 & 12.41 & 3.7 & - & - \\
\hline & Mean & & 4881.7 & 4.9 & 1.24 & 12.41 & 3.7 & 11.1 & 33.5 \\
\hline \multirow[t]{6}{*}{ Qatar } & $\begin{array}{l}\text { Arabic bread } \\
\text { small (pita) }\end{array}$ & 5 & 2714.1 & 2.7 & 0.69 & 6.90 & 2.1 & - & - \\
\hline & $\begin{array}{l}\text { Arabic bread big } \\
\text { (pita) }\end{array}$ & 5 & 1677.3 & 1.7 & 0.43 & 4.26 & 1.3 & - & - \\
\hline & $\begin{array}{l}\text { Arabic bread } \\
\text { brown (pita) }\end{array}$ & 5 & 1790.0 & 1.8 & 0.46 & 4.55 & 1.4 & - & - \\
\hline & $\begin{array}{l}\text { Lebanese bread } \\
\text { (white) }\end{array}$ & 5 & 1680.0 & 1.7 & 0.43 & 4.27 & 1.3 & - & - \\
\hline & $\begin{array}{l}\text { Lebanese bread } \\
\text { (brown) }\end{array}$ & 5 & 2468.3 & 2.5 & 0.63 & 6.27 & 1.9 & - & - \\
\hline & Mean & & 2065.9 & 2.1 & 0.53 & 5.25 & 1.6 & 10.5 & 15.0 \\
\hline \multirow[t]{3}{*}{ Jordan } & $\begin{array}{l}\text { White bread } \\
\text { small (Lebanese) }\end{array}$ & 4 & 1114.6 & 1.1 & 0.28 & 2.83 & 0.8 & - & - \\
\hline & $\begin{array}{l}\text { White bread } \\
\text { large (Lebanese) }\end{array}$ & 8 & 2256.3 & 2.3 & 0.58 & 5,74 & 1.7 & - & - \\
\hline & Mean & & 1685.5 & 1.7 & 0.43 & 4.28 & 1.3 & 10.3 & 12.5 \\
\hline \multirow[t]{2}{*}{ Lebanon } & $\begin{array}{l}\text { Arabic white } \\
\text { bread (Lebanese) }\end{array}$ & 10 & 2190 & 2.2 & 0.56 & 5.57 & 1.7 & - & - \\
\hline & Mean & & 2190 & 2.2 & 0.56 & 5.57 & 1.7 & 8 & 20.9 \\
\hline \multicolumn{3}{|c|}{ Mean for all countries } & 3000.1 & 3.0 & 0.76 & 7.63 & 2.3 & 10 & 22.9 \\
\hline \multicolumn{3}{|c|}{ Standard deviation } & & 1.23 & & 3.12 & & & \\
\hline
\end{tabular}

Morocco. Bread is thus a point of focus for salt reduction, with several bakeries already taking action, for example, in the Islamic Republic of Iran, Jordan, Oman, United Arab Emirates (UAE), Morocco, Bahrain, Kuwait and Qatar $(1,18,19)$.

Many Member States in the Region are currently taking active steps based on the policy guidance and recommended actions for salt reduction. Kuwait is gradually reducing the salt content of bread through its public bread supplier, which is the main supplier of bread in the market. In 2013, salt content of bread decreased by $20 \%$. This is an important public health achievement. Qatar has reduced the salt content in bread produced by its main public bread supplier (which has a one third market share) by $20 \%$ since early 2014 . This percentage reduction has already been achieved in the main bakeries. The Ministry of Health is monitoring the implementation to ensure that the salt level is maintained below the target percentage. A $10 \%$ reduction in salt content of the same bread was planned for the end of 2017. 
The Islamic Republic of Iran has adopted legislation on salt reduction in a number of products, including establishing maximum levels of salt in all types of bread $(1.8 \%)$. This level is still high and the recommendation is to set the benchmark at $1 \%$ to ensure effective salt reduction intake strategies.

Other Member States have prepared legislation on salt reduction (e.g., Jordan, Bahrain and Oman) or have revised existing legislation to develop benchmarks for salt content in bread. In Morocco an awareness campaign for 300 bakeries was carried out in the region of Grand Casablanca in 2014, resulting in $70 \%$ of the bakers committing to reduce added salt in bread. Oman and the UAE also reviewed their food standards and set the benchmark for salt content in bread at $0.5 \%$.

The present study had some limitations in terms of countries covered, representative samples for different types of bread and geographical coverage in each country. However, it was an indicative study conducted in response to the urgent need for information about the salt content in bread, which is lacking in the Region. Considering the time frame and logistic complications, the samples sizes were limited due to the countries' response and coverage. This study has created more demand by public health policy-makers at regional and national levels to conduct more comprehensive research.

\section{Recommendations}

In light of these findings, we make the following recommendations.

1. Although the levels of salt in the regional flat bread is not as high as in European bread $(2-3 \mathrm{~g} / \mathrm{kg})(16)$; the total salt intake is high in the Region due to the high consumption of bread as a staple food.
2. The amount of salt added to bread and other processed food products should be standardized and relevant legislation developed to guide bakers. Setting an upper limit for salt content in flat bread at $0.5 \%(5 \mathrm{~g} / \mathrm{kg})$ is strongly recommended for Jordan, Egypt, Lebanon, Sudan, Pakistan, Afghanistan, Oman, UAE, Qatar, Saudi Arabia and occupied Palestinian territory. However, salt levels at $1 \%(10 \mathrm{~g} / \mathrm{kg})$ or less would be good for countries with high levels of salt content in bread such as the Islamic Republic of Iran, Kuwait, Tunisia and Morocco.

3. A monitoring framework on salt usage in confectionary should be established to track compliance to set standards. Salt reduction, especially among manufacturers, should be mandatory and laws and guidelines should be drawn up to guide the process.

4. Country-wide campaigns to raise awareness of salt usage and its potential health impact should be conducted to enable the public to make informed decisions and to encourage manufacturers to lower salt intake in food products.

5. Similar studies on other food products should be carried out to identify major contributors to total salt intake in national diets.

6. Legislation on mandatory food labelling should be introduced or strengthened to facilitate the attainment of salt reduction targets and help consumers make informed decisions about salt levels in food.

Funding: This study was funded by WHO.

Conflict of interests: None declared.

\section{Évaluation de la concentration de sel dans le pain couramment consommé dans la Région de la Méditerranée orientale}

\section{Résumé}

Contexte : L'hypertension est le facteur de risque de maladies cardio-vasculaires le plus important dans la Région OMS de la Méditerranée orientale. Une consommation excessive de sel et de sodium est directement liée à l'hypertension, et sa réduction constitue une priorité pour l'OMS. Le pain est le principal produit de première nécessité dans la Région ; diminuer la quantité de sel ajouté à ce produit pourrait donc constituer une mesure efficace pour réduire l'apport en sel.

Objectif : La présente étude avait pour objectif de déterminer la teneur en sodium et en sel du pain de base produit localement dans huit pays de la Région.

Méthodes : Des échantillons de pain ont été collectés de façon aléatoire dans des boulangeries des capitales des pays sélectionnés. La teneur en sodium de ces échantillons a été analysée à l'aide de la technique de spectrométrie d'absorption atomique.

Résultats : La teneur moyenne en sel du pain variait de 4,28 g/ kg en Jordanie à $12,41 \mathrm{~g} / \mathrm{kg}$ en Tunisie. La teneur moyenne en sel et en sodium du pain pour l'ensemble des pays était de 7,63 g/kg (écart-type de 3,12) et 3,0 g/kg (écart-type de 1,23) respectivement. La contribution du pain à l'apport en sel quotidien variait considérablement selon les pays, allant de $1,3 \mathrm{~g}(12,5 \%)$ en Jordanie, à 3,7 g (33,5\%) en Tunisie.

Conclusion : Les interventions visant à diminuer la consommation de sel des individus devraient avoir pour objectif la réduction du sel ajouté au pain dans tous les pays. La quantité de sel ajouté au pain devrait être standardisée et une législation adéquate devrait être mise au point pour guider les boulangers. Il est vivement recommandé de fixer une limite supérieure pour la teneur en sel du pain plat (pita ou pain arabe) à 0,5\%. Toutefois, des teneurs en sel du pain inférieures ou égales à $1 \%$ conviendraient pour les autres types de pain. 


$$
\begin{aligned}
& \text { تقييم التركيز الملحي في الخبز الثائع الاستهلاك في إقليم شرق المتوسط إتبط } \\
& \text { أيوب الجو الدة، منال الخحايسة } \\
& \text { الخلاصة الخابة }
\end{aligned}
$$

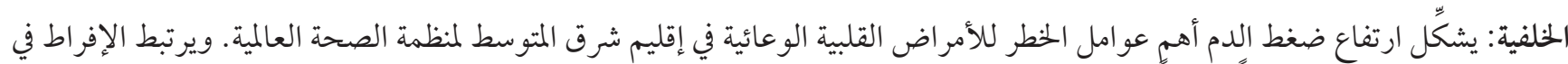

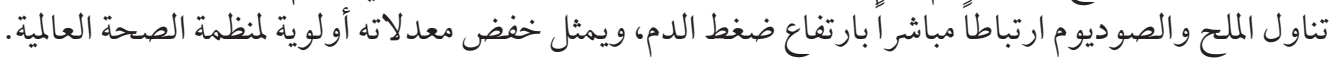

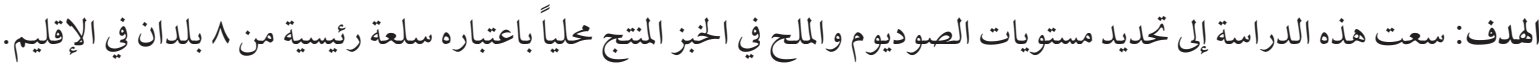

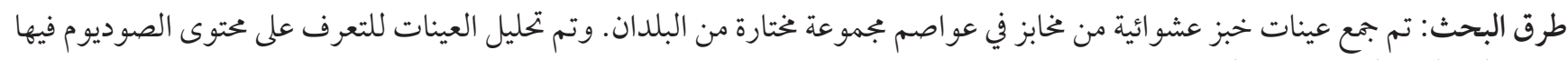

$$
\begin{aligned}
& \text { باستعمال مطياف للامتصاص الذرينات آنري. }
\end{aligned}
$$

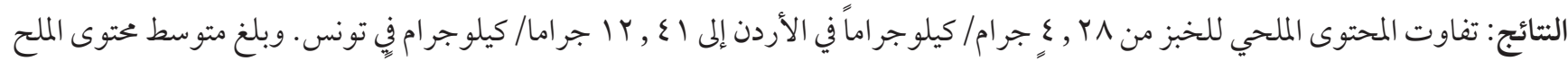

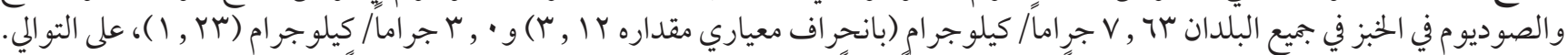

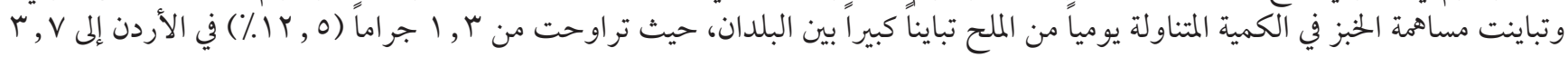

$$
\begin{aligned}
& \text { (أ) }
\end{aligned}
$$

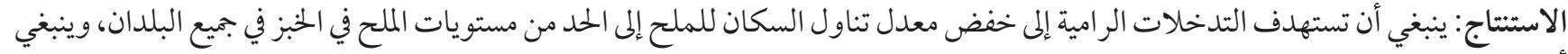

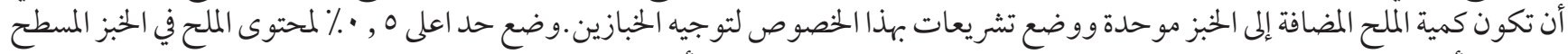

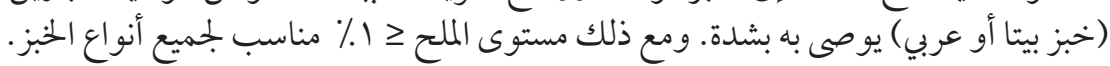

\section{References}

1. Policy statement and recommended actions to lower national salt intake and death rates from high blood pressure and stroke in the Eastern Mediterranean Region. Cairo: World Health Organization Regional Office for the Eastern Mediterranean; 2014 (http://www.emro.who.int/ nutrition/strategy/salt-policy-statement.html, accessed 13 February 2018).

2. Guideline: sodium intake for adults and children. Geneva: World Health Organization; 2012 (reprinted 2014) (http://apps.who.int/iris/bitstre am/9789241504836/1/77985/10665_eng.pdf?ua=1\&ua=1, accessed 13 February 2018).

3. Bochud M, Marques-Vidal P, Burnier M, Paccaud F. Dietary salt intake and cardiovascular disease: summarizing the evidence. Public Health Rev. 52-530:(2)33;12 2011. https://doi.org/10.1007/BF03391649

4. The World Health Report: reducing risks, promoting healthy life. Geneva: World Health Organization; 2002 (http://www.who.int/whr/2002/en/ whro2_en.pdf?ua=1, accessed 13 February).

5. Mohan S, Campbell NR. Salt and high blood pressure. Clin Sci (Lond). 2009 Jun 11-1:(1)117;2. https://doi.org/10.1042/CS20080207 PMID:19476440

6. Global status report on non-communicable diseases 2010. Geneva: World Health Organization; 2014 (http://www.who.int/nmh/publications/ ncd_report_full_en.pdf, accessed 13 February 2018)

7. Noncommunicable diseases in the Eastern Mediterranean Region. Cairo: World Health Organization Regional Office for the Eastern Mediterranean; 2016 (EMRO Technical Publications Series 43, http://applications.emro.who.int/dsaf/EMROPUB_2016_EN_18977.pdf?ua=1, accessed 15 February 2018.

8. Effect of reduced sodium intake on blood pressure, renal function, blood lipids and other potential adverse effects. Geneva: World Health Organization; 2012 (http://apps.who.int/iris/bitstream/9789241504911/1/79325/10665_eng.pdf, accessed 13 February 2018).

9. Bibbins-Domingo K, Chertow GM, Coxson PG, Moran A, Lightwood JM, Pletcher MJ, et al. Projected effect of dietary salt reductions on future cardiovascular disease. N Engl J Med. 2010 Feb 9-590:(7)362;18. https://doi.org/10.1056/NEJMoa0907355 PMID:20089957

10. Jablonski KL, Fedorova OV, Racine ML, Geolfos CJ, Gates PE, Chonchol M, et al. Dietary sodium restriction and association with urinary marinobufagenin, blood pressure, and aortic stiffness. Clin J Am Soc Nephrol. 2013 Nov;9-1952:(11)8. https://doi.org/10.2215/CJN.00900113 PMID:23929930

11. Political declaration of the high-level meeting of the General Assembly on prevention and control of noncommunicable diseases. United Nations General Assembly; 2011 (A/RES/2/66; www.who.int/nmh/events/un_ncd_summit2011/political_declaration_en.pdf, accessed13 February 2018).

12. Global action plan for the prevention and control of noncommunicable diseases 2020-2013. Geneva: World Health Organization; 2013 (http:// apps.who.int/iris/bitstream/9789241506236/1/94384/10665_eng.pdf?ua=1, accessed 13 February 2018).

13. Sixty-sixth World Health Assembly. Follow-up to the political declaration of the high-level meeting of the General Assembly on the prevention and control of non-communicable diseases (WHA66.10; http://apps.who.int/gb/ebwha/pdf_files/WHA66/A66_R-10en.pdf, accessed 13 February 2018).

14. Brown IJ, Tzoulaki I, Candeias V, Elliott P. Salt intakes around the world: implications for public health. Int J Epidemiol. 2009 Jun;813-791:(3)38. https://doi.org/10.1093/ije/dyp139 PMID:19351697

15. Anderson CAM, Appel LJ, Okuda N, Brown IJ, Chan Q, Zhao L, et al. Dietary sources of sodium in China, Japan, the United Kingdom, and the United States, women and men aged 40 to 59 years: the INTERMAP study. J Am Diet Assoc. 2010 May;45-736:(5)110. https://doi.org/10.1016/j. jada.2010.02.007 PMID:20430135

16. Salloum H. Middle Eastern breads. Backwoods Home Magazine. May/June 2012 (http://www.backwoodshome.com/middle-eastern-breads, accessed 13 February 2018). 
17. SHAKE the salt habit. The SHAKE technical package for salt reduction. Geneva: World Health Organization; 2016 (http://www.who.int/ dietphysicalactivity/publications/shake-salt-habit/en/, accessed 13 February 2018).

18. Maghroun M, Sajjadi F, Sarhanghpour MR, Nouri F, Shriatifar M, Mohammadifard N et al. [Salt and sodium content in Iranian breads]. Hakim Health Sys Res. 16-209:(3)18;2015 (in Persian) http://hakim.hbi.ir/article-1555-1-en.pdf.

19. Ali Jafri, El-Kardi Y, Derouiche A. Sodium chloride composition of commercial white bread in Morocco. East Mediterr Health J. 2017 Dec 10-708:(10)23;14. https://doi.org/2017.23.10.708/10.26719 PMID:29270972 